\title{
自動配光測定装置による光束積分
}

\author{
石 井弘允・室 井 德 雄 \\ 日本大学理工学部 東京都千代田区神田駿河台 1-8 \\ (昭和 44 年 2 月 3 日受付)
}

\section{Measurement of Total Luminous Flux by Automatic Light Distribution Measuring Equipment}

\author{
Hiromitsu IsHII and Norio MuroI \\ (College of Science and Engineering, Nihon University, Chiyoda-ku, Tokyo) \\ (Received February 3, 1969)
}

\begin{abstract}
In the case of discussing the properties of light sources and luminares, it is important to know the total luminous flux and the light distribution curve. We have studied on the automatic measurement of light distribution curve and total luminous flux for several years, and now, it is possible to measure within from a few minutes to scores seconds. In this paper, the authors described the general of the automatic light distribution measuring equipment and showed the integral method of luminous flux. In addition, we discussed the error of photometric system and made clear that the measurement by light distribution method is better than globe photometer.
\end{abstract}

\section{1. まえがき}

光源および照明器具の性能を評価するには全光束値, 配光曲線, 効率などを知ることが重要であるが, 配光 法による光束測定はきわめて測定点が多く，乙か子測 定後のデータ整理に多くの時間を費やしたので, 従来 は汪とんど実施されず，もっぱら球形光束計にたよっ ていた。

しかし球形光束計は内面塗料の反射むら打よび劣 化 ${ }^{1)}$ などにより初期の特性を保持することが困難であ りまたしゃ光板に基因する愦差 ${ }^{2)}$, 光源の自己吸収 ${ }^{3)}$ など多くの問題を包含している.

そこでわれわれは配光法による光束積分方式につい て種々検討を重ね(2) 11), 測光器系にアナログ, ディジ タル機器を適宜に使用した自動配光測定装置を作成し， 角度-時間変換方式により高精度でしかも短時間での 光束測定を実現し, 性能のすぐれていることを確認し たのでその結果を報告する。

† 第 5 回計測自動制御学会学術講演会で本文の一部を発表 (昭 $41 \cdot 9$ )

\section{2. 角度-時間変換方式による光源の 全光束積分}

自動配光測定装置を使用して配光法により全光束值 を測定するには，光源をとりをく仮想球上を受光器で くまなく走査する必要がある。これを実現する走査の 万法としては仮想球を横割りまたは縦割りにする $2 つ$ の方法が考えられる6).

\section{$2 \cdot 1$ 横割り積分方式}

光源を水平方向に一定速度で連続回転させつつ受光 器を鉛直方向に $\pi$ だ回転させる方式をとれば，横割 り積分方式となり，鉛直角 $\theta$ および水平角 $\varphi$ は（1） 式のようになる。

$$
\theta=\frac{\pi}{T_{V 1}} t \quad \varphi=\frac{2 \pi}{T_{h 1}} t
$$

ただし， $T_{V 1}$ : 受光器が鉛直方向に $\pi$ だけ回転するの に要する時間

$T_{h 1}$ : 光源の水平 1 回転時間

周知のように, 任意方向の配光光度が $I(\theta, \varphi)$ なる光 源の全光束値 $F$ は, 


$$
F=\int_{\varphi=0}^{\varphi=2 \pi} \int_{\theta=0}^{\theta=\pi} I(\theta, \varphi) \sin \theta d \theta d \varphi
$$

(2) 式で示されるので, (1)，（2）式の関係からこ の方式での全光速值 $F$ は（3）式となる.

$$
\begin{gathered}
\quad F=\frac{2 \pi^{2}}{T_{V 1}} \sum_{i=1}^{n} \int_{(i-1) T_{h 1}}^{i T_{h 1}} I(t) \sin \left(\frac{\pi}{T_{V 1}} t\right) d t \\
\text { ただし }, \quad n=T_{V 1} / T_{h 1}
\end{gathered}
$$

これは Fig. 1 に示したように仮想球を横割りにした

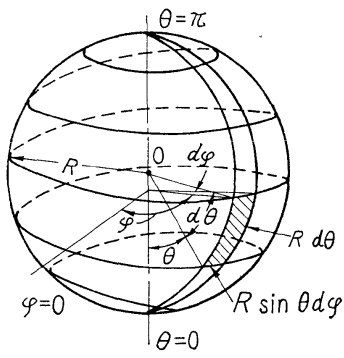

Fig. 1 Imaginary sphere

積分方法で, $n \rightarrow \infty$ とすれば受光器は仮想球全表面 を走査することになり，

$$
F=\frac{2 \pi^{2}}{T_{V 1}} \int_{0}^{T_{V 1}} I(t) \sin \left(\frac{\pi}{T_{V 1}} t\right) d t
$$

となる。

\section{2 縦割り積分方式}

光源を中心とする仮想球上で受光器を鉛直方向に連 続回転させつつ光源を水平方向に $\pi$ だけ回転させると，

Fig. 2 のように球を縦割りにした状態で光束積分を

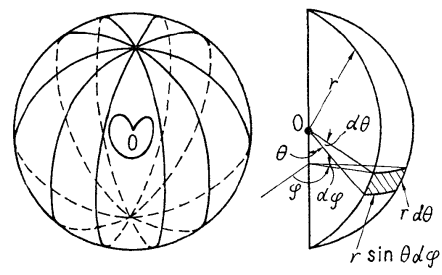

Fig. 2 Imaginary sphere

行なうことになる. 受光器の鉛直 1 回転時間を $T_{V 2}$, 光源が水平方向に $\pi$ だけ回転するのに要する時間を $T_{h 2}$ とすれば, 全光束值 $F$ は,

$$
F=\frac{2 \pi^{2}}{T_{h 2}} \sum_{i=1}^{m} \int_{(i-1) T_{V 2}}^{i T_{V 2}} I(t)\left|\sin \frac{2 \pi}{T_{V 2}} t\right| d t
$$

ただし， $\quad m=T_{h 2} / T_{V 2}$

となる。また $m \rightarrow \infty$.では全球面を走査することにな り,

$$
F=\frac{2 \pi^{2}}{T_{h 2}} \int_{0}^{T_{h}} I(t)\left|\sin \frac{2 \pi}{T_{V 2}} t\right| d t
$$

（6）式となる.

\section{$2 \cdot 3$ 横割り, 縦割り両積分方式の比較}

このように全仮想球面を受光器でくまなく走査する 方式としては，横割り，縦割りの 2 つの方式が考兄ら れる。横割り方式はさきにも述べたよらに，光源を水

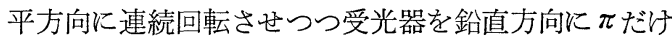
回転させる方式であるから，測定時間を短縮するため には, 光源を水平方向に高速度で回転させる必要が生 じ，そのため光源に振動を与えるなどの悪影響があり， 白熱電球などにおいてはフィラメントを破損すること もある。したがって測定時間の短縮を目的とする自動 配光測定装置の光束積分方式としてはあまり適当な方 法とはいえない。

これに対し，縦割り方式は受光器を高速回転させ， 光源を水平方向に低速回転させる方式であるから, 光 源に悪影響を与えないで，しかも“測定時間の短縮” という利点を有している。

そこでわれわれはこの縦割り方式を採用し，光束積 分を行ならため，鏡 3 面を使用した自動配光測定装置 を作成し，受光器を回転させるかわりに，鏡を鉛直方 向に高速回転させる光束積分方式を実現した。

\section{3. 自動配光測定装置}

\section{$3 \cdot 1$ 配 光 装 置}

試作した自動配光装置は Fig. 3 に示したように測 光軸対称の構造を有し，鉛直回転部分が高速回転にた えられるような構造になっている．装置の大きさは高 さ $3 \mathrm{~m}$, 奥行 $2.4 \mathrm{~m}$ で, 受光器側よりみた正面図の 円形わくは $2.6 \mathrm{~m}$ である.

被測定光源はファインダ $\mathrm{F}$ 用いて，鏡 $\mathrm{M}_{1}$ の回転 中心 $\mathrm{S}$ に設置するが，設置方向は上向き，下向き点灯 および水平点灯が可能なようになっている. 光源から の光束は縦 $750 \mathrm{~mm}$, 横 $500 \mathrm{~mm}$ の鏡 $\mathrm{M}_{1}, \mathrm{M}_{2}, \mathrm{M}_{3}$ によって, 測光ベンチ上に設置した測光軸延長上の固 定受光器に導入されるので, 光源の水平回転括よび鏡 の鉛直回転によって全立体角の光束が受光器にはいり, 直径 $500 \mathrm{~mm}$ までの光源および照明器具の全光束值 を測定することができる．また光源は直流 0 〜 $150 \mathrm{~V}$ ， $6 \mathrm{~A}$, 安定度 $\pm 0.02 \%$ 以内括よび交流 $80 \sim 120 \mathrm{~V}$, $20 \mathrm{~A}, 160 \sim 240 \mathrm{~V}, 10 \mathrm{~A}$, 安定度 $\pm 0.2 \%$ 以内の電 源によりスリップリングを用いて点灯するようになっ ている.

\section{$3 \cdot 2$ 駆 動 機 構}

本装置の鏡および光源の駆動機構は Fig. 4 に示し たように，1kW の同期電動機を滅速し，その出力唓 よりそれぞれの伝動系を分岐している。鏡は光源側と 受光器側の並列駆動方式を採用し, 装置のねじれおよ. 


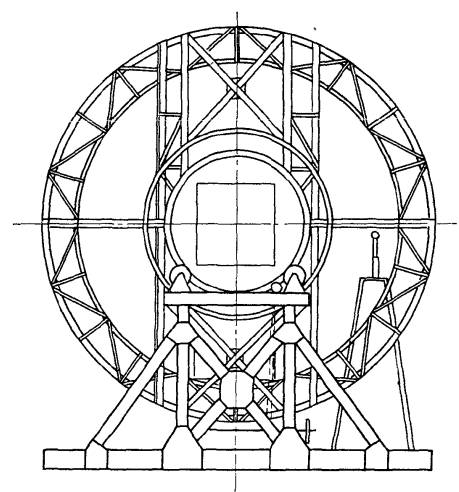

(a) a side view

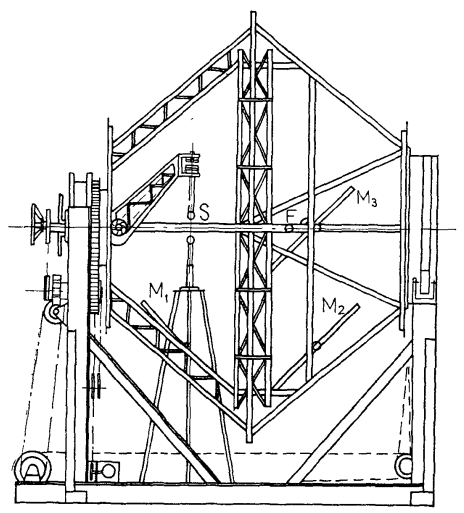

(b) a front view

Fig. 3 The structure of light distribution measuring equipment

び慣性による回転もらを除去するため, 受光器側をべ ルト結合により駆動している。鏡の鉛直回転速度は 6 , $3,1.5 \mathrm{rpm}$ の 3 段階に設定でき, 鏡 1 回転時間で移 動する光源の水平回転角は $1^{\circ} \sim 60^{\circ}$ の範团で 9 段階に 設定できるようになっている．測定中鏡の回転数と光 源の回転数は $n: 1$.の比を保つことにより，2.2 で述 ベた縦割り積分方式を実現することができる。

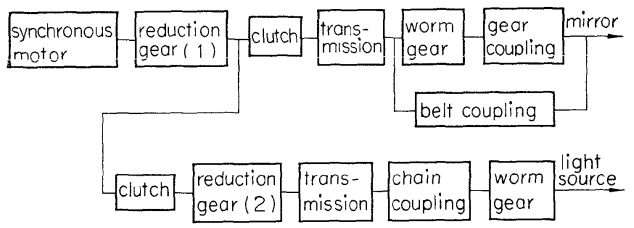

Fig. 4 Driving system

\section{$3 \cdot 3$ 測 光 器系 概 要}

Fig. 5 に示したように測光器系は受光器, $\sin$ 関数 発生器, $\mathrm{V}-\mathrm{F}$ 変換器, パルスカウンタ, ディジタル プリンタによって構成されている. 受光器は 2 次電子 増倍管を使用して㧍り, 暗流, リーク電流执よび増倍 率の変動を軽減するため, 電圧 $700 \mathrm{~V}$ 以下, 安定度

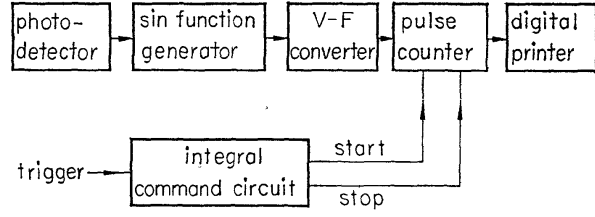

Fig. 5 Photometric system for luminous flux integration

$\pm 0.015 \%$ 以内の電源を用いている. 分光感度はガラ スフィルタ和よびプラスティクフィルタを組み合わせ 極力規準視感度に一致するように調整し，白熱電球の 色温度変化に対する補正率は Fig. 6 に示したよらに， 色温度 $2354^{\circ} \mathrm{K} \sim 2900^{\circ} \mathrm{K}$ の範囲で $0.3 \%$ 以内である。 sin 関数発生器は流入電流々 $\sin$ 関数抵抗の積を出 力とするもので, 直径 $160 \mathrm{~mm}$ の円形を成し, 温度 上昇による熱起電力の影響を軽減させるためオイルを 封入し冷却している. Fig. 7 はこの $\sin$ 関数発生器 の精度を負荷抵抗 $3 \mathrm{M} \Omega$ で測定した結果であり誤差 は土0.25\%以内である。

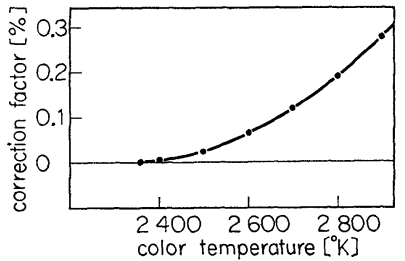

Fig. 6 Correction factor of photo-detector on the variation of color temperature

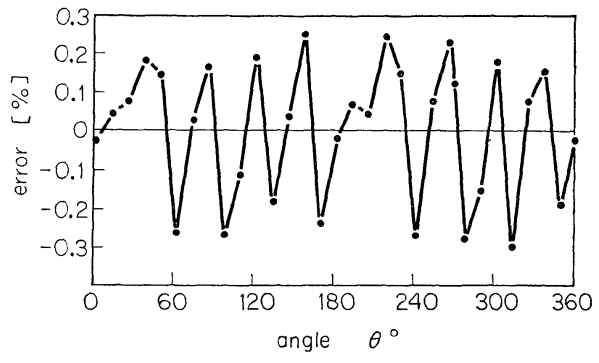

Fig. 7 Error of sin function generator

また $\sin$ 関数発生器の出力電圧をディジタル量に 変換する V-F 変換器は Fig. 8 に示したように, 積 分回路, 比較回路, パルス発生回路より構成されてい る積分形 A-D 変換器で, 出力パルス数は入力電圧の 積分值に比例し, 次のような性能を有している。

\section{V-F 変換器の性能}

入力電压: $\mathrm{DC} 0 \sim 1 \mathrm{~V}$

極性：正, 負

入力抵抗: $1 \mathrm{M} \Omega$

出力周波数 : $0 \sim 100 \mathrm{kHz}$ 


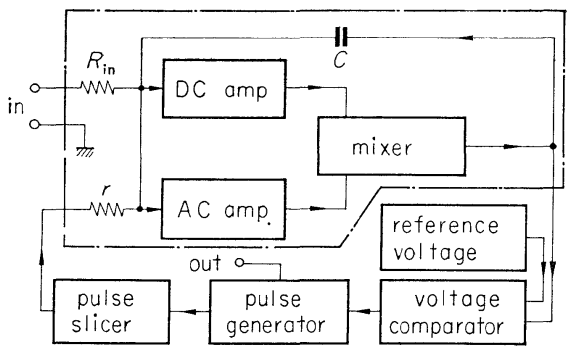

Fig. 8 Blockdiagram of $\mathrm{V}-\mathrm{F}$ convertor

出力パルス・幅 $2.5 \mu \mathrm{s}$

直 線 性: $\pm 0.002 \%$

正 確さ: $\pm 0.02 \%$ 以内

温度係数: $1^{\circ} \mathrm{C}$ に対し読みの $\pm 0.001 \%$ 以内

\section{4. 測 定 方 法}

$2 \cdot 2$ でも述べたように光源の全光束值を測定するに は, 受光器で仮想球の全表面をくまなく走査すること が理想である．そこでわれわれは光源と受光器を結ぶ 線上のほぼ中間に水平方向に幅を持たせた拡散板を設 置し，等価的に受光器の水平幅を広げ，仮想球全表面 をこの拡散板で走査することにより, 綎割り積分方式 による理想的な全球面走査法を考案した。

この全球面走査法では拡散板幅 $W$ と水平分割角度 $\varphi_{0}$ との関係は次のようになる.

$$
W=2 R \tan \left(\varphi_{0} / 2\right)
$$

ただし， $R$ : 光源から拡散板までの実効半径

$$
\varphi_{0}=\pi T_{V 2} / T_{h 2}
$$

本装置では縦 $10 \mathrm{~cm}$, 横 $23.2 \mathrm{~cm}$ のオパールグラ スを拡散板として使用し, 光源と拡散板および受光器 と拡散板の間でそれぞれ逆 2 乗則が成立するように拡 散板幅 $(23.3 \mathrm{~cm})$ の張る水平角が $5^{\circ}$ になるよらに設 定した。

測定は鏡の回転開始によって自動的に行なわれるよ らになって捛り，鏡が始めに $\theta=0^{\circ}$ を通過したとき の光トリガ信号によって計数を開始させ, 光源が水平 方向に $180^{\circ}$ 回転し，かつ鏡が $\theta=0^{\circ}$ を通過したとき の信号により停止させ，カウンタの指示をディジタル プリンタで印字させる方法である，

Fig. 9 (a)，（b ）はこの方式に和ける測定状態の

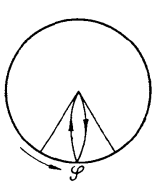

(a)

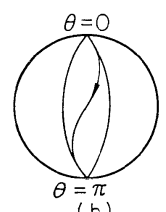

(b)

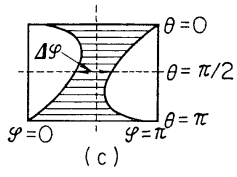

(c)
Fig. 9 A locus of photo-detector 受光器中心の軌跡を示したもので（a）は仮想球の頂 点からみた場合であり，（b ）は側面から見たもので， Fig. 9 (c) は鏡が $0^{\circ} \sim 180^{\circ}$ 女で回転したときの拡 散板の軌跡を展開図上に示したものである。

Fig. 10 中水平分割角度 $5^{\circ}$ の測定結果は全球面走 查法により白熱電球の全光束值を测定したときの測定 值のばらつきを示したもので，その範囲は $\pm 0.2 \%$ 以 内である。

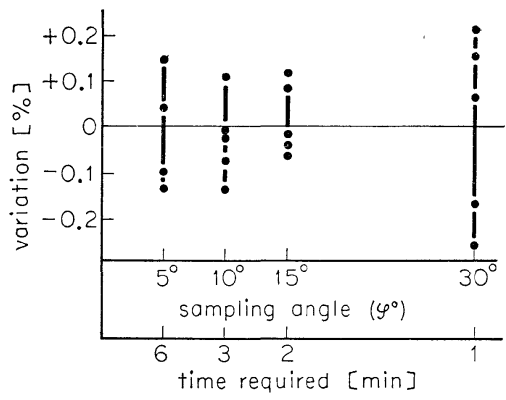

Fig. 10 Variation of measurement value

しかし白熱電球のよらに水平配光曲線が比較的円形 を成している光源では水平角を適当に抢ろぬき走査し たほらが，測定時間の短縮にも有利であり，また測定 時間の長さからくる不安定要素を軽減することも考学 られる。これを確かめるため，水平分割角度を $10^{\circ}$, $15^{\circ}, 30^{\circ}$ に設定し, 積分した結果は Fig. 10 に示し たようになり，10および $15^{\circ}$ 分割では $\pm 0.15 \%$ 以 内, $30^{\circ}$ 分割では $\pm 0.25 \%$ 以内のばらつきとなっ た。

これらの結果より, 縱割り積分方式で光源の全光束 值を測定するには，拡散板の幅を水平方向に広げ，水 平分割角度を適当におろぬき，走査したほうが測定時 間の短縮もでき, 全球面走査を行ならよりも時間の長 さから生ずる䛊差を軽減できるのでかえって有利であ, る.

\section{5. 測光器系おくれ要素による 誤差の吟味}

自動配光測定装置の測光器系はそれぞれ 1 次おくれ 要素をもつ機器の直列接続によって構成されることが 多く, 受光器入射光の時間的变化のため报くれ要素に よる誤差を生ずる心配がある。そこでこの誤差を吟味 するため, 幾何学的配光曲線を有する直線光源, 平面 板光源および半球面光源を例にとり，配光指示誤差 ${ }^{9}$, の最大值を求めると, 直線光源扎よび平面板光源で法

（8）式，半球面光源では（9）式となり,

$$
\varepsilon_{1}=\frac{2 \pi \tau T_{V 2}}{4 \pi^{2} \tau^{2}+T_{V 2}^{2}}
$$




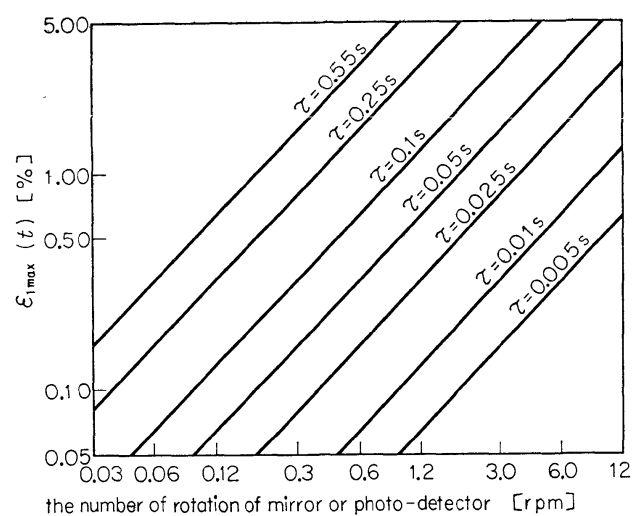

Fig. 11 Maximum errors of light distribution measurement value of linear source and circular disc source

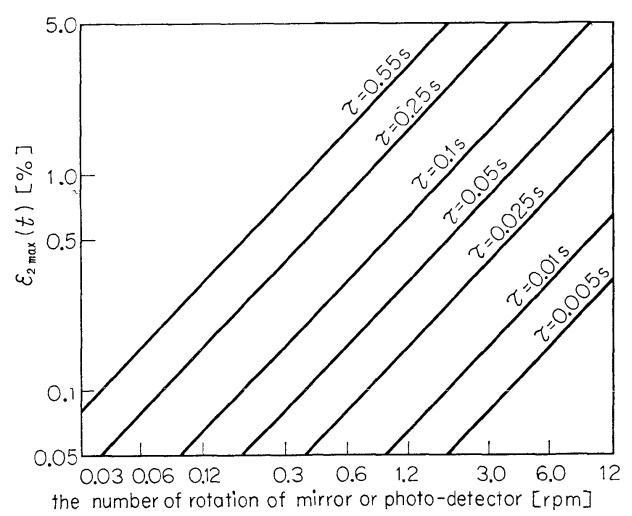

Fig. 12 Maximum errors of light distribution measurement value of half spherical surface sorce

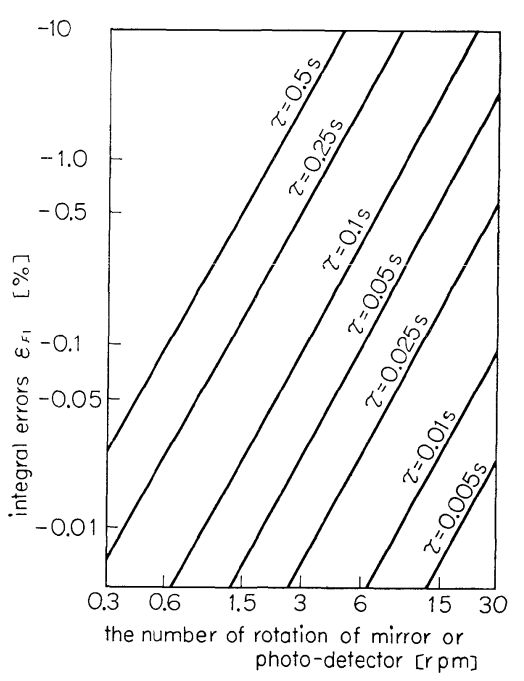

Fig. 13 Integral errors of total luminous flux in case of linear light source

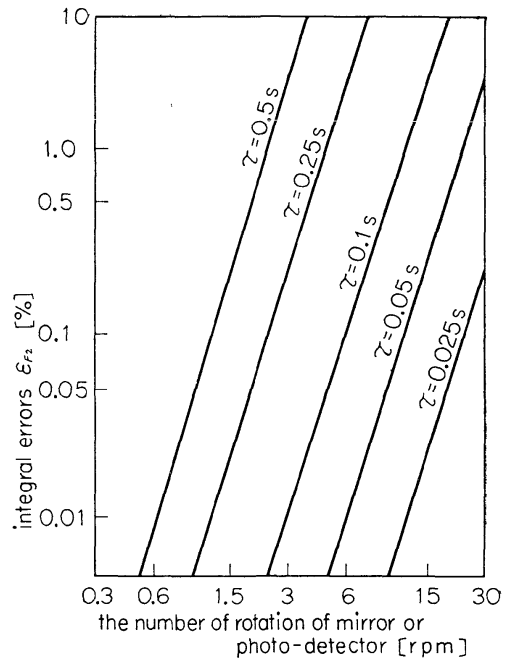

Fig. 14 Integral errors of total luminous flux in case of circular disc light source

$$
\varepsilon_{2}=\frac{\pi \tau}{\sqrt{4 \pi^{2} \tau^{2}+\bar{T}_{V 2}^{2}}}
$$

ただし， $\tau:$ 測光器系の定時数

図示すると Fig. 11, Fig. 12 となる.

また，直線光源および平面板光源の全光束測定誤 差9)はそれぞれ（10）式および（11）式によって計算 され,

$$
\begin{aligned}
\varepsilon_{F 1} & =\frac{4 \pi^{2} \tau^{2}\left(8 \tau T_{V 2}-4 \pi^{2} \tau^{2}-T_{V 2}^{2}\right)}{\left(4 \pi^{2} \tau^{2}+T_{V 2}{ }^{2}\right)^{2}} \\
\varepsilon_{F 2} & =\frac{4\left(\pi^{2} \tau^{2} T_{V 2}^{2}-4 \pi^{4} \tau^{4}\right)}{\left(4 \pi^{2} \tau^{2}+T_{V 2}^{2}\right)^{2}}
\end{aligned}
$$

Fig. 13，Fig. 14 のような結果になる.

よって本装置の測光器系時定数は $0.6 \mathrm{~ms}$ であり, 鏡を $12 \mathrm{rps}$ で回転させ使用しても十分さしつか党な いことがわかる。

\section{6. 白熱電球の全光束值測定例}

白熱電球の全光束值を角度-時間変換方式によって 測定した結果を Table 1 亿示す.

Table 1 は A 社より光束標準電球として, 測定值 付きた販売されている白熱電球を縦割り積分方式で測 定した結果と他の機関で測定した值を比較したもので， 拡散板を使用した例は，拡散板の水平幅を水平角 $5^{\circ}$ に設定して測定した結果で, 測定所要時間は 2 分であ る。

そしてこの結果から各光束比のばらつきを求めると $\pm 0.3 \%$ 以内であり，自動配光測定装置のみによる測 定值のばらつきでは $0.2 \%$ 以内であることが明ら かである.これは自動配光測定装置による光束比の測 定が $\pm 0.3 \%$ 以内の精度で十分行ない得ることを示 


\begin{tabular}{|c|c|c|c|c|c|c|}
\hline light source & \multicolumn{3}{|c|}{ Nihon University } & $A$ (company) & $B$ (laboratory) & average \\
\hline (A) $60 \mathrm{~W}$ & $6.83_{7} \times 10^{2} \mathrm{~lm}$ & 6. $82_{1} \times 10^{2} 1 \mathrm{~m}$ & 6. $82_{6} \times 10^{2} \mathrm{~lm}$ & 7. $0_{6} \times 10^{2} \mathrm{~lm}$ & 7. $0_{7} \times 10^{2} \mathrm{Im}$ & $6.92_{3} \times 10^{2} \mathrm{~lm}$ \\
\hline (B) $60 \mathrm{~W}$ & $7.17_{8} \times 10^{2} \mathrm{~lm}$ & $7.15_{2} \times 10^{2} \mathrm{Im}$ & $7.15_{7} \times 10^{2} \mathrm{~lm}$ & 7. $4_{4} \times 10^{2} \mathrm{~lm}$ & 7. $4_{2} \times 10^{2} \mathrm{Im}$ & $7.21_{9} \times 10^{2} \mathrm{~lm}$ \\
\hline flux ratio, $B / A$ & 1.050 & 1.049 & 1.048 & 1.054 & 1.050 & 1.050 \\
\hline (C) $100 \mathrm{~W}$ & & 1. $27_{8} \times 10^{3} \mathrm{~lm}$ & $1.27_{6} \times 10^{3} \mathrm{~lm}$ & 1. $3_{4} \times 10^{3} \mathrm{~lm}$ & 1. $3_{5} \times 10^{3} \mathrm{~lm}$ & 1. $31_{1} \times 10^{3} \mathrm{~lm}$ \\
\hline (D) $100 \mathrm{~W}$ & 1. $41_{0} \times 10^{3} \mathrm{~lm}$ & 1. $40_{5} \times 10^{3} \mathrm{~lm}$ & 1. $40_{7} \times 10^{3} \mathrm{~lm}$ & 1. $4_{7} \times 10^{3} \mathrm{~lm}$ & 1. $4_{8} \times 10^{3} \mathrm{~lm}$ & 1. $43_{4} \times 10^{3} \mathrm{~lm}$ \\
\hline (E) $100 \mathrm{~W}$ & 1. $48_{1} \times 10^{3} \mathrm{~lm}$ & 1. $48_{0} \times 10^{3} \mathrm{~lm}$ & $1.47_{9} \times 10^{3} \mathrm{Im}$ & 1. $5_{4} \times 10^{3} \mathrm{~lm}$ & $1.5_{5} \times 10^{3} 1 \mathrm{~m}$ & 1. $50_{6} \times 10^{3} \mathrm{~lm}$ \\
\hline flux ratio, $C / D$ & & 0.9096 & 0.9067 & 0.9116 & 0.9122 & 0.9142 \\
\hline flux ratio, $E / D$ & 1.050 & 1.053 & 1.051 & 1.048 & 1.047 & 1.050 \\
\hline \multirow{2}{*}{$\begin{array}{l}\text { measuring } \\
\text { equipment }\end{array}$} & \multicolumn{3}{|c|}{ light distribution method } & \multirow{2}{*}{ unknown } & \multirow{2}{*}{$\begin{array}{l}\text { globe } \\
\text { photometer }\end{array}$} & \\
\hline & \multicolumn{2}{|c|}{ use of opal glass } & 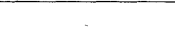 & & & \\
\hline time reqired & \multicolumn{2}{|c|}{$2 \mathrm{~min}$} & $(\min$ & & & \\
\hline date & 1966, $7 \sim 8$ & 1966,3 & 1965,10 & $\begin{array}{r}\text { 60W 1964, } 12 \\
100 \mathrm{~W} 1965,3\end{array}$ & 1965,8 & \\
\hline
\end{tabular}

Table 1 Measuring example of total luminous flux on tungsten lamps

しており, 今後光度標準電球の取り扱いなどに留意す れば, 光度から光束值の值付拜十分可能になる。

\section{7. 球形光束計法との比較}

球形光束計により $I(\theta, \varphi)$ の配光をもつ光源の全光 束値を測定する場合は（12）式で表わすことができる.

$$
F=\int_{\varphi} \int_{\theta} K(\theta, \varphi) \cdot I(\theta, \varphi) \cdot \sin \theta \cdot d \theta \cdot d \varphi
$$

そして積分能力は光束計内面塗料の反射率，乙ゃ光 板の大きさおよびしゃ光板の位置によって定まる係数 $K(\theta, \varphi)$ 曲線2),4) によって決定される.

いっぽう，自動配光測定装置を使用した縦割り積分 方式による全光束値は，

$$
F=\frac{2 \pi^{2}}{T_{h 2}} \int_{0}^{T_{h 2}} I(t) \cdot \varepsilon(t)\left|\sin \frac{2 \pi}{T_{v 2}} t\right| d t
$$

となり， $\varepsilon(t)$ の大きさで積分能力が決定される.

Fig. 15 はこの $K(\theta, \varphi)$ 曲線と角度-時間変換方式 の誤差基因量 $\varepsilon(t)$ を比較したもので，この図より明 らかなよらに自動配光測定装置による誤差のほうが小 さい. また球形光束計の $K(\theta, \varphi)$ 曲線は時間的に静 止しているため，ただちにこれが光束測定值の精密さ になるとは限らないので, 一見精密測定に適するかと 思われがちであるが， $\varepsilon(t)$ は積分能力からみた精密 さと正確さを含めた精度を示すものであるから，積分 能力よりみた正確さといら点では自動配光測定装置を 使用した角度一時間変換方式のほうがすぐれていると いえよう。

Fig. 16 は角度時間変換方式の積分能力を調査する

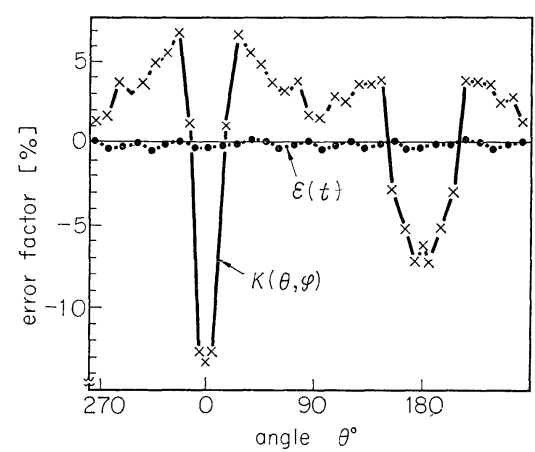

Fig. 15 Comparison of accuracy

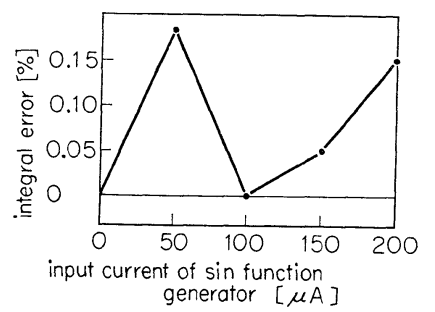

Fig. 16 Integral error

ため, 受光器光電流を一定に保ち, 均等点光源と等価 な状態で動作させ，計算值に対する誤差を示したもの で，この結果からも積分能力は $\pm 0.2 \%$ 以内である ことが確かめ得た。

\section{8. む す び}

以上述べたように, 自動配光測定装置を使用し, 縦 割り積分方式で全光束值を測定する方法は, その積分 能力の点からみれば球形光束計よりすぐれており, 測 
定時間も光源と受光器の間に適当な幅の拡散板をそう 入し，水平角のおろぬき走査を行なえば，鏡の回転数 $6 \mathrm{rpm}$ では $60 \mathrm{~s}$ 程度で,ささらに本装置では鏡の回転 数を $12 \mathrm{rpm}$ まであげられるよらに設計されているの で $30 \mathrm{~s}$ に短縮することもでき, 球形光束計にくらべ てそん色がなくなる。また測定精度も土0.3\% 以内 で, 測定後のデータ処理もきわめて簡単であるから， 今後光源および照明器具の開発にあたり，十分その成 果を活用できるものと確信している。

\section{参 考 文 献}

1）横地：正立方形光束計内面の活れに就て, 照明学会雑 誌, 20-5, p.222 (1936)

2）室井 : 遮光板に基因する光束計の誤差, 照明学会雑誌, 42-10, 450/455 (1958)

3）室井・松村：球形光束計に和ける吸収について，昭和 32 年 4 月電気四学会連合大会論文集，531 (1957)

4) 室井・石井：球帯係数の追尾演算方式による全光束の 自動測定について，昭和 38 年電気関係学会関西支部
連合大会講演論文集，S 16-4，p. 366 (1963)

5)．室井・石井・島野：配光測定装置の自動化機構とその 測光器系の一例について, 昭和 40 年照明学会東京支 部大会講演論文集, 8, p. 37 (1965)

6）室井・石井：自動配光法による光源の全光束測定につ いて, 昭和 40 年照明学会東京支部大会講演論文集, 7, p. 31 (1965)

7）室井・石井・吹野：自動配光装置の受光系時定数によ る配光指示誤差について，昭和 39 年電気四学会連合 大会論文集, 984 (1964)

8）室井・石井：配光法（光源，鏡の同時回転方式）によ る全光束値と受光系時定数との関係，昭和 39 年電気 四学会連合大会論文集, 985 (1964)

9）石井・佐々木・室井 : 自動配光測定装置の測光器系時 定数による誤差, 照明学会雑誌, 50-1，4/11 (1966)

10）室井・石井・肥後：自動配光測定装置の測光系総合時 定数について, 昭和 41 年電気四学会連合大会論文集, 614 (1966)

11）室井・石井 - 島野：全球面走査法による光源の全光束 測定, 昭和 41 年電気四学会連 合大会論文集, 617 (1966) 